\title{
APPLICATION OF ARTIFICIAL NEURAL NETWORKS AND PRINCIPAL COMPONENT ANALYSIS ON VIBRATION SIGNALS FOR AUTOMATED FAULT CLASSIFICATION OF ROLLER ELEMENT BEARINGS
}

\author{
ZASTOSOWANIE SZTUCZNYCH SIECI NEURONOWYCH ORAZ ANALIZY \\ GŁÓWNYCH SKŁADOWYCH SYGNAŁU DRGAŃ \\ DO AUTOMATYCZNEJ KLASYFIKACJI USZKODZEŃ ŁOŻYSKTOCZNYCH
}

\begin{abstract}
The article addresses the implementation of feature based artificial neural networks and vibration analysis for automated roller element bearings faults identification purpose. Vibration features used as inputs for supervised artificial neural networks were chosen based on principal component analysis as one of the possible methods of data dimension reduction. Experimental work has been conducted on a specially designed test rig and on a drive of the Ganz port crane in port of Novi Sad, Serbia. Different scalar vibration features derived from time and frequency domain were used as inputs to fault classifiers. Several types of roller elements bearings faults, at different levels of loads were tested: discrete faults on inner and outer race and looseness. It is demonstrated that proposed set of input features enables reliable roller element bearing fault identification and better performance of applied artificial neural networks.
\end{abstract}

Keywords: roller elements bearing, vibration, artificial neural network, principal components analysis.

\begin{abstract}
Artykut omawia zastosowanie sztucznych sieci neuronowych opartych na cechach oraz analizy drgań do celów automatycznej identyfikacji uszkodzeń tożysk tocznych. Cechy drgań mające postużyć jako dane wejściowe do nadzorowanych sztucznych sieci neuronowych wybrano na podstawie analizy głównych składowych, która stanowi jedna z metod zmniejszania rozmiaru zbioru danych statystycznych. Badania prowadzono na specjalnie do tego celu zaprojektowanym stanowisku badawczym oraz na uktadzie napędu żurawia portowego firmy Ganz w porcie Novi Sad w Serbii. Jako wejścia klasyfikatorów uszkodzeń wykorzystano różne skalarne cechy drgań określone w dziedzinie czasu i częstotliwości. Badano kilka typów uszkodzeń tożysk tocznych przy różnych poziomach obciażenia: uszkodzenia dyskretne w obrębie pierścienia wewnętrznego i zewnętrznego tożyska oraz nadmierny luz. Wykazano, że proponowany zbiór cech wejściowych umożliwia niezawodna identyfikację uszkodzeń tożysk tocznych oraz zapewnia lepsza wydajność zastosowanych sztucznych sieci neuronowych.
\end{abstract}

Słowa kluczowe: łożysko toczne, drgania, sztuczna sieć neuronowa, analiza głównych składowych.

\section{Introduction}

The ultimate goal of every maintenance strategy in a modern plant is to avoid high maintenance costs and productions risks due to the rotating machine's fault. High costs are initiated through the production stops and losses while the production risks are related to the secondary failures of the neighboring machines. Monitoring the machine's health through the implementation of condition based maintenance strategy is based on acquisition and trending the physical parameter that is found to be sensitive to machine degradation. Several methods of non-destructive testing are available nowadays, such as vibration measurement and analysis, infrared thermography, noise measurement, motor current signature analysis, wear particle analysis, ultrasound measurements etc. Mechanical vibration acquired at the bearing's housing (absolute vibration) or directly on a rotating part (relative vibration) is one of the best parameter for early detection of a developing fault inside a machine. If appropriate vibration transducer is engaged and mounted properly and if proper signal processing methods has been used for the suspected fault, then we can say that the vibration signal contains unambiguous information on the existing state of the machine. Methods of vibration signature analysis enable the extraction of type and severity of a fault inside the rotating machine. However the existing guidelines are not universal due to the facts that there may be multiple faults inside the machine and that the content of the acquired vibration signals are dependent on the severity of the fault and on the variation of the rotating speed and load. As a result, derivation of incorrect conclusions and wrong estimation of machine criticality in the plant, is a very common situation. We can avoid this by engagement of highly skilled certified vibration analysts or by the implementation of artificial intelligence (AI) techniques for reliable extraction of an existing fault. In the absence of certified vibration analysts inside the maintenance team the implementation of AI methods through previously developed and validated fault identification algorithm has a promising potential.

For the purpose of automatic machine health determination through automatic fault identification there are several applicable methods of AI such as supervised and unsupervised artificial neural networks (ANN), fuzzy logic, expert systems and hybrid intelligence systems. The most applied are ANN $[14,1]$ due to their ability to learn i.e. to adopt novelties. This adaptability of ANN results in a possibility for detection of an existence of a new condition (fault) based on the existing data $[13,6]$. In addition, ANN are found to be efficient in modeling of highly complex nonlinear phenomena that are present in several types of rotating machinery faults. Several types of ANN are successfully 
implemented in automatic fault identification $[3,7,8,12,16,17,18$, 20]: back propagation feed forward network (BPFF), multiple layer perceptron network (MLP), back propagation multiple layer perceptron (BPMLP), radial basis function network (RBF), self-organized feature map (SOFM). An excellent review of different types of ANN and training algorithms implementation for different types of rotating machinery faults can be found in [10]. The increasing trend of implementation of MLP with back propagation training algorithm, with the number of neurons in hidden layers taken as a variable, is evident.

The success of ANN in identification and classification of machine fault is highly dependent on the definition of the cloud of input variables i.e. on the definition of the most representative vibration features that are sensitive on the fault occurrence and progression over the time. One vibration feature could be appropriate for one type of vibration fault while on the other hand it can be unresponsive for other type of fault.

As a preprocessing tool for selecting the most important vibration features, we used principal component analysis (PCA). PCA is one of the most frequently used multivariate data analysis technique. One of the main goals of PCA implementation is the reduction of dimensionality of the input set of vibration features. Basically it is defined as an orthogonal linear transformation that transforms the cloud of input variables to a new coordinate system in a way that the greatest variance of the input features are aligned on the first coordinate (called the first principal component), the second greatest variance on the second coordinate, and so on. As a result, possibly correlated input features are converted into a set of values of linearly uncorrelated variables that we call principal components.

Roller element bearings are present in all types of rotating machines and often they are claimed to be the most critical parts of the machine and the main culprits of the machine failures. If we add to this the fact that roughly just $10 \%$ [11] of the bearings run for their complete design life then we can see that development of signal processing techniques and data preprocessing methods combined with the algorithms of ANN is prominent in maximizing the reliability of rotating machinery.

A successful implementation of ANN and PCA for the identification of rotating machine faults can be found in $[2,15,4,9]$. The authors used different scalar features obtained from vibration data as inputs for neuron classifiers.

In this paper, we used vibration scalar features obtained from frequency and time domains. The initial definition of vibration features is done based on an assumption that these features are sensitive to bearing failures tested in this paper.

\section{Vibration analysis techniques for roller element bear- ings failures identification}

Roller element bearing can prematurely fail due to different reasons (Figure 1) and its failure can be initiated through different mechanisms such as: fatique crack, wear, plastic deformation of bearing components, corrosion, brinelling phenomena etc. Often, these mech-

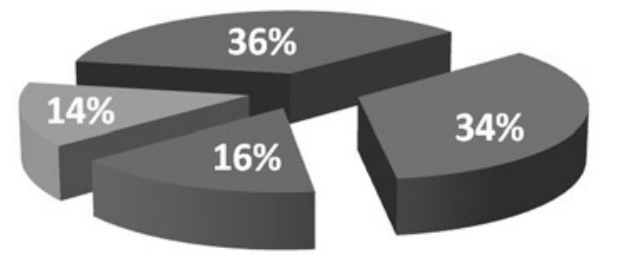

- Fatique $34 \%$

- Handling and installation errors $16 \%$

= Contamination $14 \%$

- Lubrication problems $36 \%$

Fig. 1. Most common mechanisms for bearing failure [11] anisms are overlapping inside the bearing. It is also possible that one mechanism activates the initial damage and that over the time another mechanism runs the bearing to the final failure $[19,16]$.

If we follow the best practices on proper lubrication, handling and installation of bearings then the most expected mechanism of bearing degradation is a material fatigue crack. In that case, roller element bearing which is subjected under the projected dynamic load will fail due to the occurrence of the fatigue crack. Due to the bearing geometry, the most expected place of initial crack occurrence is under the contact surface of internal race and the roller element. If such a bearing is left in operation under the load, the crack is expanding and occurs at the surface on the bearing race (Figure 2). The next stage of bearing degradation is the enlargement of the crack. At that stage other cracks might occur. Flaws from the race damage other components of the bearing and we have a spalling inside a bearing. As a final result we have a bearing with excessive looseness.
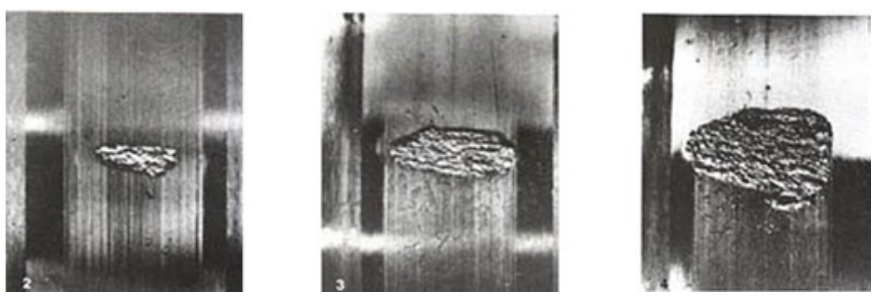

Fig. 2. Development of crack on the internal race of the bearing

Ball bearing has four basic components: inner and outer race, roller elements and a cage. If we have a discrete crack on one of these components, then we have a chance to identify its characteristic forcing frequency in time and frequency domain. Based on the geometry of the bearing we can calculate these frequencies: BPFI (ball pass frequency of inner race), BPFO (ball pass frequency of outer race), BS (ball pass frequency) and CF (cage frequency).

The content of vibration signal from the bearing with a developing damage is highly dependent on the type and stage of degradation [19]. At the initial stage, we can see only minor impacts masked in noise. At later stages the crack develops and impacts are high enough to cause the bearing's natural frequency $\left(f_{\text {res }}\right)$ excitement. Such a case, with the single crack on the inner race and with BPFI $=4.1 \mathrm{X}$, where $\mathrm{X}$ stands for the first harmonic order (shaft speed), is numerically simulated and shown on Figure 3.

Time waveforms from Figure 3 reveal some interesting facts regarding vibration signals from faulty bearing. Signal is a sum of high amplitude and low frequency component from $1 \mathrm{X}$ and low amplitude and high frequency components from impacts that are generated every time when the ball hits the crack. Due to the presence of impulse excitation, the system response is in the form of exponentially decayed harmonic component at the bearing's natural frequency. The periodicity of impacts corresponds to the characteristic fault frequency (BPFI in the present case) so in the frequency spectrum we can see sidebands at this fault frequency centered around bearing's natural frequency. In cases when the fault rotates inside the bearing (fault on the inner ring or on the roller) we have an amplitude modulation of the fault frequency component. The carrier frequency is the fault frequency

while the modulation frequency is the speed of the fault inside the bearing and is shown on Figure 3. The peak amplitudes of the impulses are not equal during a revolution of the shaft due to the fact that the fault (crack on the inner race in this case) comes in and goes out from the bearing load zone. BPFI component will be amplitude modulated with the $1 \mathrm{X}$ component. In case of a crack on a roller the BS component will be modulated with the $\mathrm{CF}$ since the cage holds the rollers and determines the speed of the rollers. In a case of a crack on the outer race, we do not expect amplitude modulation around the BPFO component. 

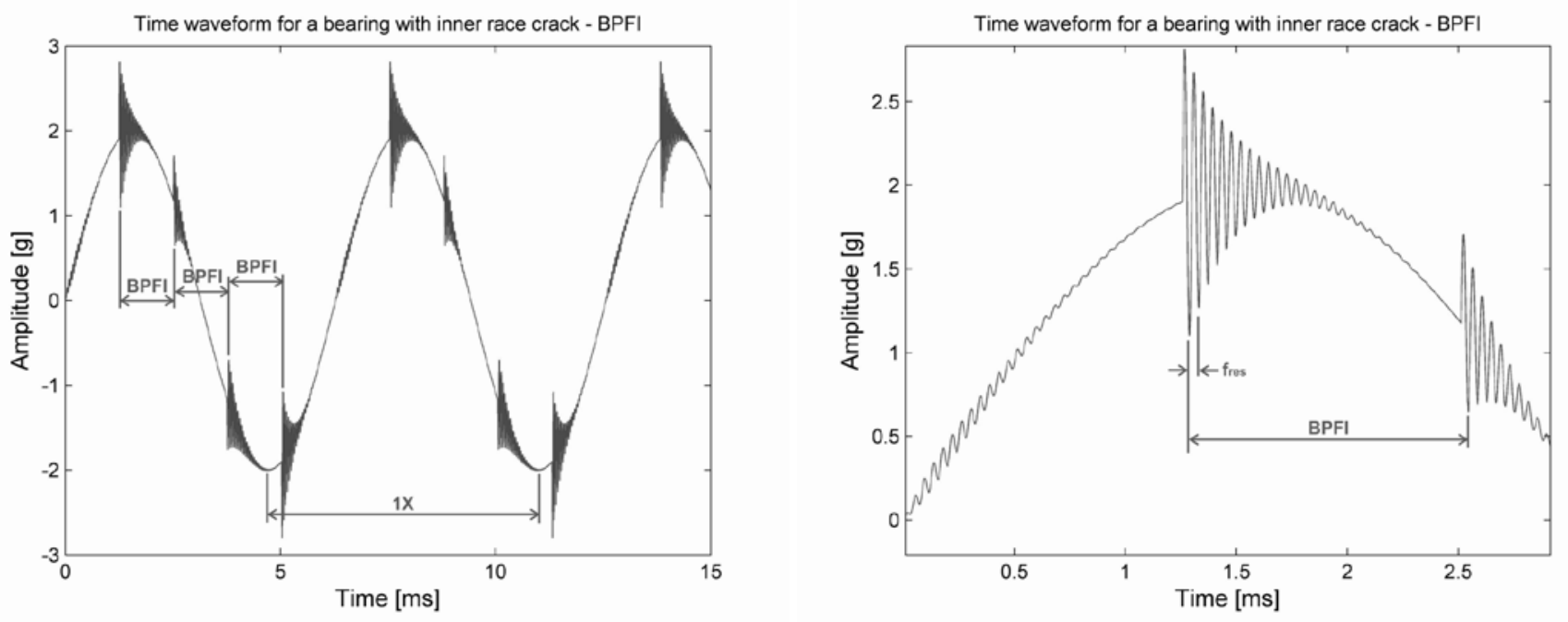

Fig. 3. Bearing with inner race crack - time waveform generated by numerical simulation

As a fault develops, we can expect higher harmonics of bearing fault frequencies, harmonics of the fundamental frequency and a broadband noise level increase due to the excessive looseness. Frequency spectra from a bearing with an outer race damage located in the load zone and with an excessive looseness is shown on Figure 4. Two harmonic families ( $1 \mathrm{X}$ and $\mathrm{BPFO})$ as well as raised broadband noise is easy to see. Frequency spectra recorded on the test rig is shown on Figure 5.

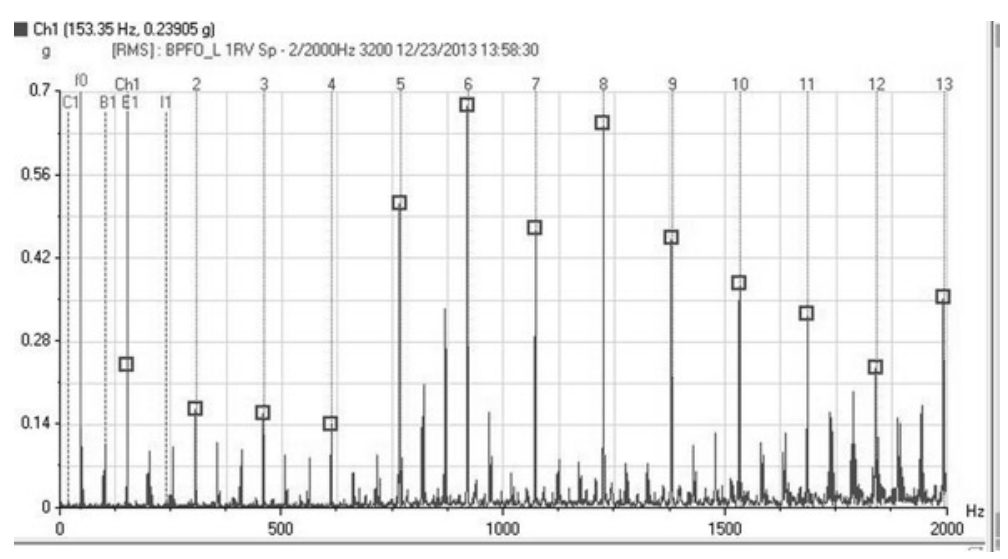

Fig. 4. Frequency spectra from a bearing with an excessive looseness and outer race fault. Harmonic cursor on BPFO family

Vibration signals from faulty bearings can be analysed using wellknown methods of signal processing in time, frequency and time frequency domains. Analysis in time domain can be performed on raw and on filtered signals. Time domain analysis is usefull in later stages of bearing degradation since the impulses from discrete cracks and from excessive looseness are then visible. In addition, it is worth to mention that it is necessary to measure acceleration of vibration due to its high sensitivity to high frequency phenomena. Since faulty bearings generate family of harmonics, which can be treated as periodicity in frequency domain, Cepstrum analysis can be used also. Dominant peaks in cepstrum can indicate the presence of $1 \mathrm{X}$ harmonics (looseness in bearings) and amplitude modulations (inner race and roller fault). Analysis in frequency domain is mainly based on analysis of classic Fast Fourier Transform (FFT) and on analysis of acceleration envelope spectra. FFT is an effective tool in analysis of moderate and heavy damages in bearings while the envelope spectra is the most effective universal tool for identification of early faults in bearings. Envelope spectra is calculated on band pass filtered time waveform com- bined with the methods of signal demodulation. The aim of the band pass filtering is removal of high amplitude low frequency component and enhancement of the high frequency part of the spectra where natural frequency of the bearing amplitude modulated with the bearing fault frequency is located. As a result, we get the envelope spectra with the harmonics of the fault frequency. By measuring the relative height of these bearing fault frequencies from the carpet noise, we could quantify the bearing health state. However, in the later stage of the bearing degradation, we have an increase of the broadband noise, which remains in the resulted envelope spectra. In that case, the component of the bearing fault frequencies are masked in the noise and, despite the bearing's state gets worser, we get a decrease in bearing fault frequencies relative height. For some bearing faults, we get the non-stationarity in vibration signal so methods of analysis, both in frequency and time domain can be used. Some of them are Short Time Fourier Transform (STFT) and wavelet analysis.

For the purpose of vibration trending and implementation of ANN we have to define scalar vibration features that increase with damage development. Due to the impact phenomena, which is present in faulty bearings, acceleration parameters should be used. For later stages of bearing degradation, features based on vibration velocity can be used also.

\section{Experimental set up and results}

The test rig, designed for the purpose of dataset collection, is shown on the Figure 5. The test rig consists of a $0.37 \mathrm{~kW}$ variable frequency drive connected over the flexible coupling to the shaft with two disks for unbalance introduction. Shaft is supported by two single row roller element bearings, type UC201A. The bearing fault frequencies, in term of harmonic orders, are: $\mathrm{BPFI}=4.9 \mathrm{X}, \mathrm{BPFO}=3.1 \mathrm{X}, \mathrm{BS}$ $=2.1097 \mathrm{X}$ and $\mathrm{CF}=0.3875 \mathrm{X}$.

Bearing vibrations were measured in radial directions, using industrial type IEPE accelerometers mounted at the roller element bearing housings using mounting studs. Input shaft speed is measured using a non-contacting laser sensor and a reflective mark. Vibration and tacho signals were acquired simultaneously using multichannel vibration analyzers NetdB, OneproD MVX, dbFA and XPR software from $01 \mathrm{db}-M e t r a v i b$. All the tests were performed at the $22 \mathrm{~Hz}$ of input speed.

Before the test impact hammer was used to excite the bearing in order to record its natural frequency. Natural frequency was found at $4.026 \mathrm{kHz}$. 


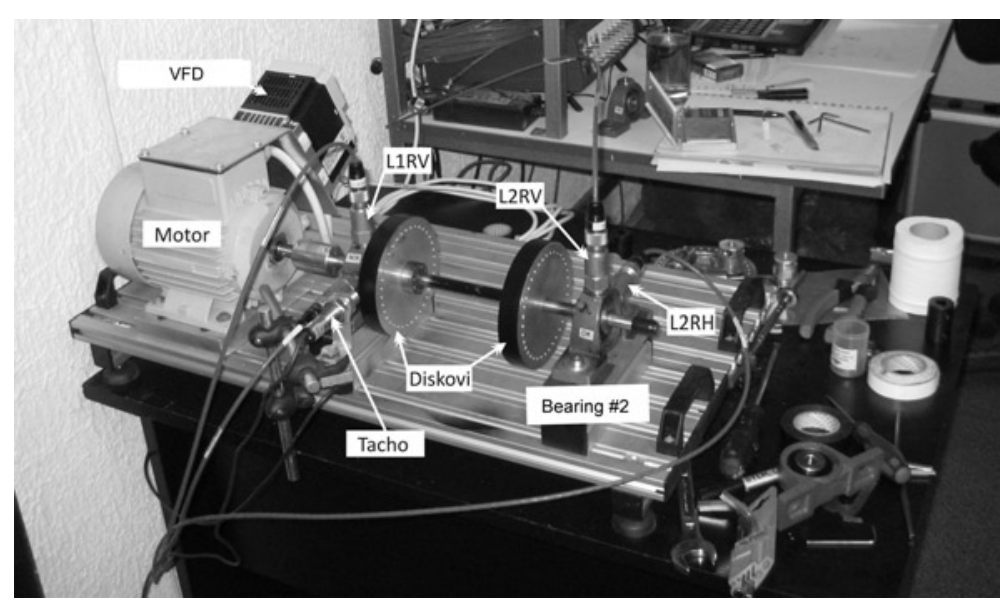

Fig. 5. Test rig used for vibration acquisition on faulty bearings

Table 1. Test rig data: labels for different unbalance levels and bearing fault types

\begin{tabular}{|c|c|c|c|c|c|c|c|c||}
\hline \multicolumn{2}{|c|}{} & \multicolumn{7}{|c||}{ Bearing fault type } \\
\cline { 2 - 10 } \multicolumn{2}{|c|}{} & OK & I & II & OL & OU & Z1 & Z3 \\
\hline \multirow{4}{*}{$\begin{array}{c}\text { Unbalance } \\
\text { levels }\end{array}$} & $\mathrm{A}$ & $\mathrm{AOK}$ & $\mathrm{AI}$ & $\mathrm{All}$ & $\mathrm{AOL}$ & $\mathrm{AOU}$ & $\mathrm{AZ1}$ & $\mathrm{AZ3}$ \\
\cline { 2 - 9 } & $\mathrm{C}$ & $\mathrm{COK}$ & $\mathrm{BI}$ & $\mathrm{BII}$ & $\mathrm{BOL}$ & $\mathrm{BOU}$ & $\mathrm{BZ1}$ & $\mathrm{BZ3}$ \\
\cline { 2 - 9 } & $\mathrm{D}$ & $\mathrm{DOK}$ & $\mathrm{DI}$ & $\mathrm{DII}$ & $\mathrm{DOL}$ & $\mathrm{DOU}$ & $\mathrm{DZ1}$ & $\mathrm{DZ3}$ \\
\hline
\end{tabular}

Table 2. Test rig data: vibration features from the original dataset

\begin{tabular}{|c|c|l|c||}
\hline Number & Label & \multicolumn{1}{|c|}{ Description } & Unit \\
\hline 1 & RMS & RMS of vibration velocity in range $2 \mathrm{~Hz}-1 \mathrm{kHz}$ & $\mathrm{mm} / \mathrm{s}$ \\
\hline 2 & $\mathrm{~S} 1$ & Amplitude of the 1 X vibration velocity component & $\mathrm{mm} / \mathrm{s}$ \\
\hline 3 & SumS & Sum of first seven harmonics of vibration velocity & $\mathrm{mm} / \mathrm{s}$ \\
\hline 4 & Kurt & Kurtosis parameter & - \\
\hline 5 & Acc2-300 & RMS of acceleration in range $2 \mathrm{~Hz}-300 \mathrm{~Hz}$ & $\mathrm{~g}$ \\
\hline 6 & Acc2-2000 & RMS of acceleration in range $2 \mathrm{~Hz}-20 \mathrm{kHz}$ & $\mathrm{g}$ \\
\hline 7 & Acc2-20000 & RMS of acceleration in range $2 \mathrm{~Hz}-20 \mathrm{kHz}$ & $\mathrm{g}$ \\
\hline 8 & Def & Defect factor ${ }^{1}$ & - \\
\hline 9 & TSS & Peak-Peak value of acceleration raw time waveform & $\mathrm{g}$ \\
\hline 10 & BPFO & Amplitude of the first harmonic of BPFO & $\mathrm{g}$ \\
\hline 11 & SumBPFO & Sum of amplitudes of first four harmonics of BPFO & $\mathrm{g}$ \\
\hline 12 & BPFI & Amplitude of the first harmonic of BPFI & $\mathrm{g}$ \\
\hline 13 & SumBPFI & Sum of amplitudes of first four harmonics of BPFI & $\mathrm{g}$ \\
\hline 14 & BS & Amplitude of the first harmonic of BS & $\mathrm{g}$ \\
\hline 15 & SumBS & Sum of amplitudes of first four harmonics of BS & $\mathrm{g}$ \\
\hline 16 & FT & Amplitude of the first harmonic of FT & $\mathrm{g}$ \\
\hline 17 & SumFT & Sum of amplitudes of first four harmonics of FT & $\mathrm{g}$ \\
\hline \hline
\end{tabular}

Four levels of unbalance were introduced on both disks: $22.5 \mathrm{gmm}$, $54 \mathrm{gmm}, 136.5 \mathrm{gmm}$ and $345 \mathrm{gmm}$, and we assigned them the following labels A, B, C and D, respectively. With every unbalance level, bearings with the following faults were tested: bearing in health condition $(\mathrm{OK})$, small (I) and moderate (II) crack on the inner race, moderate crack on outer race with a crack located in the loading (OL) and unloaded (OU)

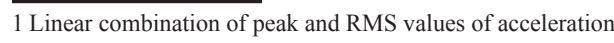

zone, moderate (Z1) and excessive (Z3) lossenes. This results in total of 28 states with label definition shown on Table 1.

Cracks on inner and outer race were introduced with small grinder tool. Smaller crack on the inner race is $0.1 \mathrm{~mm}$ deep while the moderate crack is $0.2 \mathrm{~mm}$ deep. The width of the cracks is $1 \mathrm{~mm}$. The crack on the outer race is $1 \mathrm{~mm}$ wide and $0.2 \mathrm{~mm}$ deep. Looseness has been introduced by adding a small amount of abrasive material (sand) in the grease and leaving such a bearing in operation (one hour for moderate and three hours for excessive looseness). After that, the contaminated grease has been replaced with a new one.

Despite the main goal of this research was a bearing fault identification we also introduced unbalance as a fault type. The main motivation behind this was the fact that in reality multiple faults are present on the machine and that reliable ANN should identify both unbalance level and the type and severity of the bearing fault. There are many rotating machines that can develop unbalance over time, such as fans or pumps with unbalance growth (impeller in contact with abrasive fluids or dirt accumulated on impeller).

Vibration acquisition included the measurement of: raw time waveforms, narrow band FFT in different frequency ranges with 3200 lines of resolution $(2 \mathrm{~Hz}-2 \mathrm{kHz}, 2 \mathrm{~Hz}-5 \mathrm{kHz}, 2 \mathrm{~Hz}-20 \mathrm{kHz})$ and envelope spectra. Based on these measurements 17 scalar features were extracted. Their labels and description are shown in Table 2.

The definition of the vibration features has been guided by the type of the faults we are trying to identify. The unbalance presence and levels should be sensitive to the first harmonic of the vibration velocity [16]. Faulty bearings generate raised levels of accelerations in different frequency ranges based on exact type of the bearing fault and on the severity of the fault. In case of discrete cracks on different bearing's components higher vibration levels are generated at characteristic frequency of the bearing fault and on its harmonics. This is taken into account through amplitude extraction from the frequency spectra. First harmonics of the characteristic frequencies (BPFO, BPFI, BS, FT) and sums of their first four harmonics were defined. In case of looseness, high levels of acceleration peak values and harmonics of $1 \mathrm{X}$ component are generated. The number of harmonics are dependent on the severity of the looseness. Therefore, peak to peak values and acceleration overall values in different frequency ranges were defined. Labels 1-9 in Table 2, correspond to the time domain while labels 10-17 are extracted from frequency spectra (frequency domain).

For every combination of unbalance level and bearing type (Table 1), 150 recordings were acquired. Vibrations were acquired with a periodicity of 3 minutes between them. This resulted in input matrix with 17 columns (vibration features) and 4200 rows (data).

MLP ANN applied in this paper had a classification task - to detect an exact bearing defect type (Table 1). Several architectures of MLP ANN were tested by the means of choosing the optimal network architecture from the point of the number of neurons in the hidden layer, type of activation functions and type of the learning algorithm. For building, testing and training, Statistica Automatic Neural Networks package has been used. 2940 input vectors (70\% of the dataset) were used for training while 1260 input vectors were used for cross verification and testing. The software automatically determined network complexity. 20 networks were tested. As a result the best performance network had 15 neurons in the hidden layer and the accuracy of classification of $85.714 \%$. The confusion matrix for this ANN is shown on table 3. 
Table 3. Test rig data: confussion matrix for best performance MLP ANN with 17 input features

\begin{tabular}{|c|c|c|c|c|c|c|c|c|c|c|}
\hline & $\mathrm{Al}$ & All & AOK & $\mathrm{AOL}$ & $\mathrm{AOU}$ & AZ1 & AZ3 & $\mathrm{BI}$ & BII & BOK \\
\hline Total & 150 & 150 & 150 & 150 & 150 & 150 & 150 & 150 & 150 & 150 \\
\hline Correct & 150 & 150 & 150 & 150 & 150 & 150 & 150 & 150 & 0 & 150 \\
\hline Incorrect & 0 & 0 & 0 & 0 & 0 & 0 & 0 & 0 & 150 & 0 \\
\hline Correct (\%) & 100 & 100 & 100 & 100 & 100 & 100 & 100 & 100 & 0 & 100 \\
\hline Incorrect (\%) & 0 & 0 & 0 & 0 & 0 & 0 & 0 & 0 & 100 & 0 \\
\hline & BOL & BOU & BZ1 & BZ3 & $\mathrm{Cl}$ & Cll & COK & COL & $\mathrm{COU}$ & CZ1 \\
\hline Total & 150 & 150 & 150 & 150 & 150 & 150 & 150 & 150 & 150 & 150 \\
\hline Correct & 150 & 150 & 150 & 0 & 150 & 150 & 150 & 150 & 150 & 150 \\
\hline Incorrect & 0 & 0 & 0 & 150 & 0 & 0 & 0 & 0 & 0 & 0 \\
\hline Correct (\%) & 100 & 100 & 100 & 0 & 100 & 100 & 100 & 100 & 100 & 100 \\
\hline Incorrect (\%) & 0 & 0 & 0 & 100 & 0 & 0 & 0 & 0 & 0 & 0 \\
\hline & CZ3 & DI & DII & DOK & DOL & DOU & DZ1 & DZ3 & \multicolumn{2}{|c|}{ All cases } \\
\hline Total & 150 & 150 & 150 & 150 & 150 & 150 & 150 & 150 & \multicolumn{2}{|c|}{4200} \\
\hline Correct & 0 & 150 & 150 & 150 & 0 & 150 & 150 & 150 & \multicolumn{2}{|c|}{3600} \\
\hline Incorrect & 150 & 0 & 0 & 0 & 150 & 0 & 0 & 0 & \multicolumn{2}{|c|}{600} \\
\hline Correct (\%) & 0 & 100 & 100 & 100 & 0 & 100 & 100 & 100 & \multicolumn{2}{|c|}{85.714} \\
\hline Incorrect (\%) & 100 & 0 & 0 & 0 & 100 & 0 & 0 & 0 & \multicolumn{2}{|c|}{14.286} \\
\hline
\end{tabular}

Table 4. Test rig data: eignevalues, individual and cumulative variance for PCs

\begin{tabular}{||c|c|c|c||}
\hline & Eigenvalues & \% Total variance & Cumulative $\%$ \\
\hline PC1 & 10.64789 & 62.63465 & 62.63465 \\
\hline PC2 & 2.27647 & 13.39103 & 76.02568 \\
\hline PC3 & 1.67373 & 9.84548 & 85.87116 \\
\hline PC4 & 1.17158 & 6.89164 & 92.76280 \\
\hline PC5 & 0.80524 & 4.73673 & 97.49954 \\
\hline PC6 & 0.28139 & 1.65523 & 99.15477 \\
\hline PC7 & 0.09024 & 0.53083 & 99.68559 \\
\hline
\end{tabular}

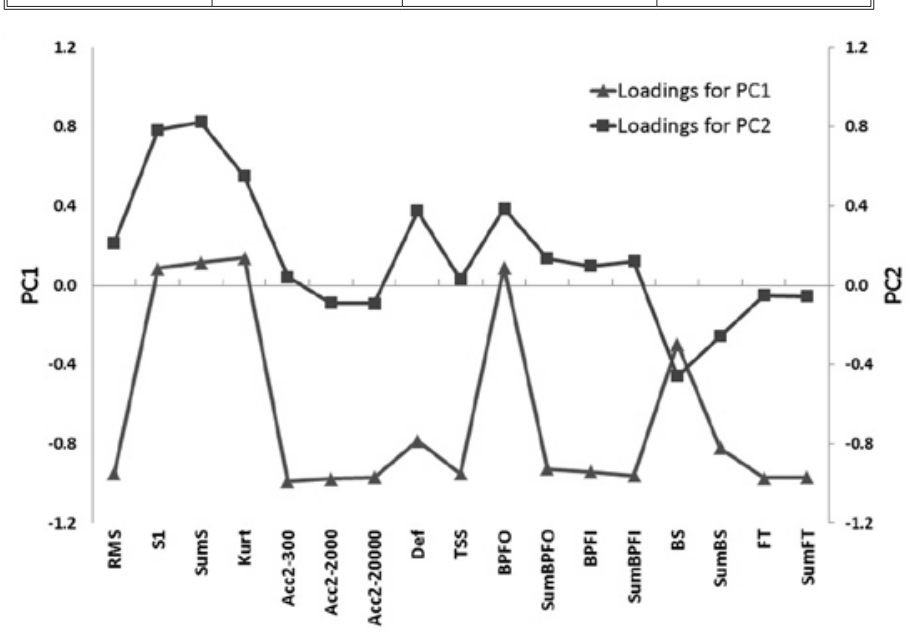

Figure 6. Test rig data: Loadings for PC1 and PC2

Table 3 reveals some interesting facts. The classification rate is either $100 \%$ or $0 \%$. Some cases (BII, BZ3, CZ3 and DOL) are completely missed. Therefore, a PCA is conducted on the input dataset to define a dataset with reduced dimension in order to find MLP ANN with better performance. As a result of PCA, 7 principal components (PCs) have been extracted with the eigenvalues shown on table 4 .

If we choose the first four PCs with eigenvalues larger than one (criterion proposed by Kaiser in 1960) then we can say that using a 4 dimension PC input space we described the original input dataset with a total of $92.76 \%$ of variance. The most influential vibration features for such a space are variables with the highest loadings i.e. highest projection on the coordinate of these dominant PCs. Loadings for each variable for PC1 and PC2 are shown on Figure 6.

The importance of each feature, calculated through modeling power, is based on how well it is represented by the PC model. Features with high modeling power are relevant for the PC model while the variables with low modeling power can be discarded.

Table 5. presents modeling power for each input feature and its importance. As relevant features, first 9 were chosen and this defined the reduced set of input features (Acc2-300, S1, Acc2-2000, SumBPFO, SumBPFI, SumS, RMS, FT and Acc2-20000). Using input matrix with these 9 vibration features several architectures of MLP ANN were tested. As a result the best performance network had 13 neurons in the hidden layer and the accuracy of classification of $99.738 \%$. The confusion matrix for this ANN is shown on table 6. As it can be seen the classification success is much better. There are no completely missing faults as it was the case with the MLP ANN with complete dataset with 17 input features. Only one case for AOU, BZ3, COU, DOL, DZ3 and six cases for CZ3 were incorrectly classified (Table 7).

Table 5. Test rig data: modeling power for each feature and its importance to PC model

\begin{tabular}{|c|c|c|c|c|c|}
\hline Feature & Power & $\begin{array}{l}\text { Impor- } \\
\text { tance }\end{array}$ & Feature & Power & $\begin{array}{l}\text { Impor- } \\
\text { tance }\end{array}$ \\
\hline Acc2-300 & 0.994766 & 1 & SumFT & 0.959409 & 10 \\
\hline S1 & 0.985738 & 2 & SumBS & 0.946349 & 11 \\
\hline Acc2-2000 & 0.985107 & 3 & BPFI & 0.944689 & 12 \\
\hline SumBPFO & 0.978242 & 4 & TSS & 0.911100 & 13 \\
\hline SumBPFI & 0.974435 & 5 & Def & 0.899415 & 14 \\
\hline Sums & 0.973051 & 6 & BPFO & 0.895808 & 15 \\
\hline RMS & 0.968662 & 7 & BS & 0.821585 & 16 \\
\hline FT & 0.963068 & 8 & Kurt & 0.606926 & 17 \\
\hline Acc2-20000 & 0.961326 & 9 & & & \\
\hline
\end{tabular}

\section{Case study}

PCA and MLP ANN for automatic identification of bearing faults were implemented on the Ganz port crane in port of Novi Sad, where an online system (Figure 7) for the crane surveillance based on strain, stress and vibration measurement has been installed [5].

During the operation of the online monitoring system, several faults were identified. One of them was the drive end (DE) bearing fault on the drive \#1 for crane rotation. In March 2014, members of the port's maintenance team reported the occurrence of raised temperatures on the bearing housing and strange noise that is typical for bearings with an excessive looseness. A quick view on the frequency spectra and its comparison with the reference measurement shows the presence of raised carpet noise and higher vibration accelerations, 
Table 6. Test rig data: confussion matrix for best performance MLP ANN with 9 input features

\begin{tabular}{|c|c|c|c|c|c|c|c|c|c|c|}
\hline & $\mathrm{Al}$ & All & AOK & $\mathrm{AOL}$ & AOU & AZ1 & AZ3 & $\mathrm{BI}$ & BII & BOK \\
\hline Total & 150 & 150 & 150 & 150 & 150 & 150 & 150 & 150 & 150 & 150 \\
\hline Correct & 150 & 150 & 150 & 150 & 149 & 150 & 150 & 150 & 150 & 150 \\
\hline Incorrect & 0 & 0 & 0 & 0 & 1 & 0 & 0 & 0 & 0 & 0 \\
\hline Correct (\%) & 100 & 100 & 100 & 100 & 99.333 & 100 & 100 & 100 & 100 & 100 \\
\hline Incorrect (\%) & 0 & 0 & 0 & 0 & 0.667 & 0 & 0 & 0 & 0 & 0 \\
\hline & $\mathrm{BOL}$ & $\mathrm{BOU}$ & BZ1 & BZ3 & $\mathrm{Cl}$ & $\mathrm{Cll}$ & COK & $\mathrm{COL}$ & $\mathrm{COU}$ & CZ1 \\
\hline Total & 150 & 150 & 150 & 150 & 150 & 150 & 150 & 150 & 150 & 150 \\
\hline Correct & 150 & 150 & 150 & 149 & 150 & 150 & 150 & 150 & 149 & 150 \\
\hline Incorrect & 0 & 0 & 0 & 1 & 0 & 0 & 0 & 0 & 1 & 0 \\
\hline Correct (\%) & 100 & 100 & 100 & 99.333 & 100 & 100 & 100 & 100 & 99.333 & 100 \\
\hline Incorrect (\%) & 0 & 0 & 0 & 0.667 & 0 & 0 & 0 & 0 & 0.667 & 0 \\
\hline & CZ3 & DI & DII & DOK & $\mathrm{DOL}$ & DOU & DZ1 & DZ3 & \multicolumn{2}{|c|}{ All cases } \\
\hline Total & 150 & 150 & 150 & 150 & 150 & 150 & 150 & 150 & \multicolumn{2}{|c|}{4200} \\
\hline Correct & 144 & 150 & 150 & 150 & 149 & 150 & 150 & 149 & \multicolumn{2}{|c|}{4189} \\
\hline Incorrect & 6 & 0 & 0 & 0 & 1 & 0 & 0 & 1 & \multicolumn{2}{|c|}{11} \\
\hline Correct (\%) & 96 & 100 & 100 & 100 & 99.333 & 100 & 100 & 99.333 & \multicolumn{2}{|c|}{99.738} \\
\hline Incorrect (\%) & 4 & 0 & 0 & 0 & 0.667 & 0 & 0 & 0.667 & \multicolumn{2}{|c|}{0.262} \\
\hline
\end{tabular}

Table 7. Test rig data: prediction errors for best performance MLP ANN with 9 input features

\begin{tabular}{||c|c|c|c||}
\hline Phase & Target - input & $\begin{array}{c}\text { Prediction - } \\
\text { output }\end{array}$ & $\begin{array}{c}\text { Number of oc- } \\
\text { currence }\end{array}$ \\
\hline Training & AOU & AOL & 1 \\
\hline Validation & BZ3 & CZ3 & 1 \\
\hline Training & COU & DOL & 1 \\
\hline Training & CZ3 & DZ3 & 3 \\
\hline Testing & CZ3 & DZ3 & 1 \\
\hline Validation & CZ3 & DZ3 & 2 \\
\hline Training & DOL & COL & 1 \\
\hline Training & DZ3 & CZ3 & 1 \\
\hline
\end{tabular}

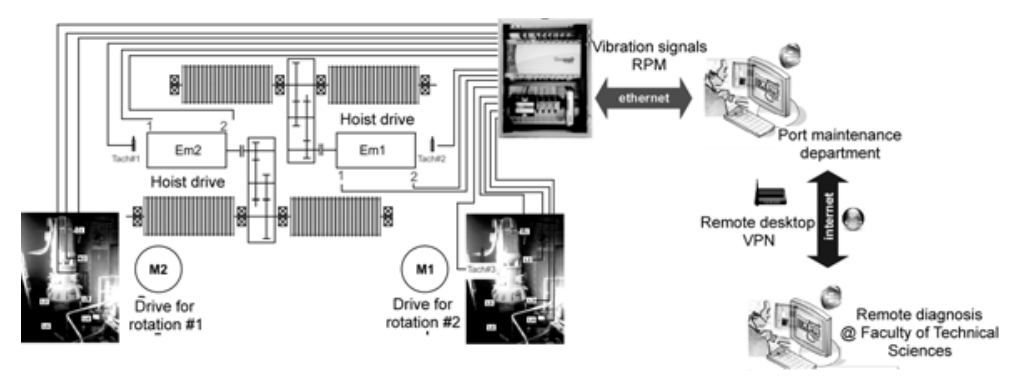

Fig. 7. Scheme of the online monitoring system installed on Ganz port crane [5]

typical for bearings with looseness. The same applies to the time waveform (Figure 8), where the presence of short duration high amplitude impacts can be seen.
Vibration acquisition included measurement of raw time waveforms and narrow band FFT in different frequency ranges with 3200 lines of resolution. Vibration features that were extracted are presented in the table 8 .

Spectral extractions at bearing fault frequencies were not defined since the exact geometry of the bearing was unkown. Vibration trends for RMS and Acc features, as examples, are shown on Figure 9. Vibration data are shown in terms of index and they cover the complete development of the bearing fault development. Two important facts are worth to mention when observing Figure 9. First, it can be seen that Acc parameter has an increasing trend with the fault development while this can not be seen in case of RMS feature. Second, the machine under surveillance works under different loads and speeds. The data presented are not filtered to the specific load and speed levels. This is one of the reason for an absence of positive trend with RMS feature.

When assigning output labels to the input vectors a constant rate of bearing fault development is assumed. The original dataset consists of 1100 individual vectors and covers the data before the high temperatures occurrence up to the date when the machine was stopped for bearing replacement. The output labels are: $\mathrm{Z1}$ (healthy bearing), Z2 (moderate looseness) and Z3 (excessive looseness). Using input matrix

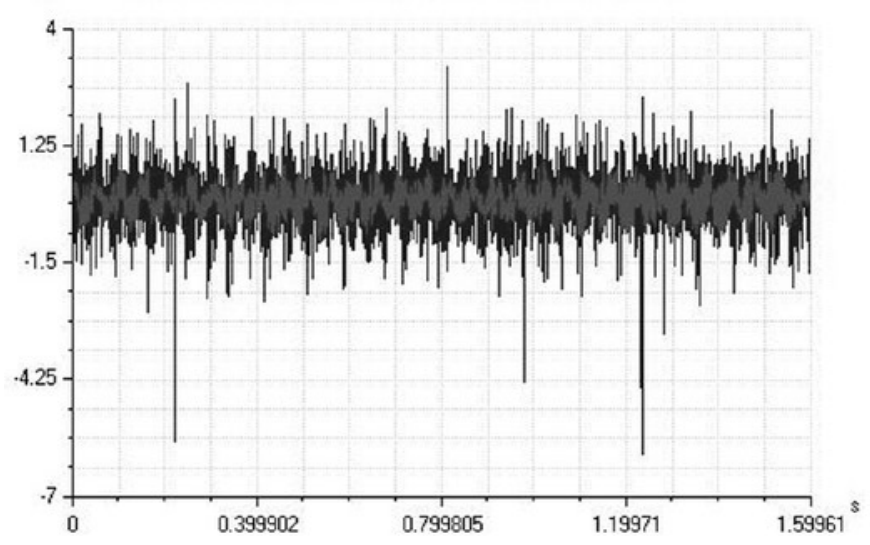

Fig. 8. Motor DE bearing: time waveforms for bearing in good and faulty state

with 9 features and 1100 labeled vectors several architectures of MLP ANN were tested. The best performance network had 13 neurons in the hidden layer and the accuracy of classification of $87.091 \%$.

PCA on the input dataset resulted in extraction of 3 PCs with eigenvalues (Table 10). First two PCs have eigenvalues larger than 1 and projecting input features on these two PCs we are describing the input features dataset with $79.06 \%$ of variance.

The importance of each feature is evaluated through modeling power and the results are shown on Table 11. Kurtosis parameters and RMS of vibration velocity were excluded from the input feature matrix for MLP ANN. Using six input features several MLP ANN were tested. The best performance network had 11 neurons in the hidden layer and the accuracy of classification of $92.337 \%$. As in the case of the test rig data, the input dataset with the reduced set of input features resulted in the MLP ANN with better classification rate (Table 12). 
Table 8. Case study data: vibration features from the original dataset

\begin{tabular}{|c|c|l|c||}
\hline Number & Label & \multicolumn{1}{|c|}{ Description } & Unit \\
\hline 1 & RMS & RMS of vibration velocity in range $2 \mathrm{~Hz}-1 \mathrm{kHz}$ & $\mathrm{mm} / \mathrm{s}$ \\
\hline 2 & Acc & RMS of acceleration in range $2 \mathrm{~Hz}-2 \mathrm{kHz}$ & $\mathrm{g}$ \\
\hline 3 & Acc_2_500 & RMS of acceleration in range $2 \mathrm{~Hz}-500 \mathrm{~Hz}$ & $\mathrm{~g}$ \\
\hline 4 & Acc_500_1000 & RMS of acceleration in range $500 \mathrm{~Hz}-1 \mathrm{kHz}$ & $\mathrm{g}$ \\
\hline 5 & Acc_1000_2000 & RMS of acceleration in range $1 \mathrm{kHz}-2 \mathrm{kHz}$ & $\mathrm{g}$ \\
\hline 6 & PeakPeak & Peak-Peak value of acceleration raw time waveform & $\mathrm{g}$ \\
\hline 7 & Def & Defect factor & - \\
\hline 8 & Kurtosis MVX & Kurtosis parameter of the raw time waveform & - \\
\hline 9 & Kurtosis Postprocess & Kurtosis parameter of the high pass filtered $(500 \mathrm{~Hz}-2 \mathrm{kHz})$ time waveform & - \\
\hline
\end{tabular}

ACC

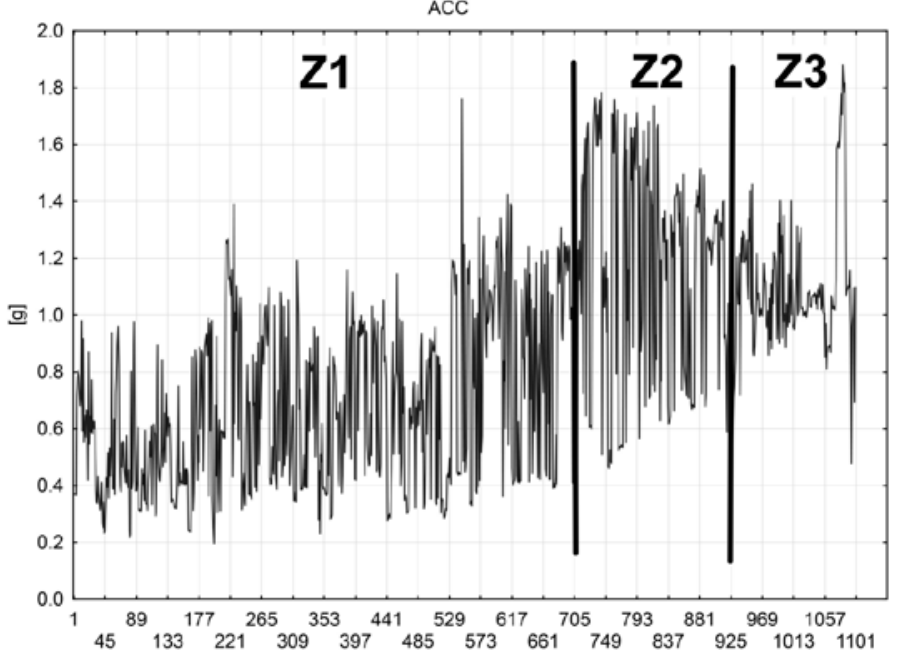

RMS

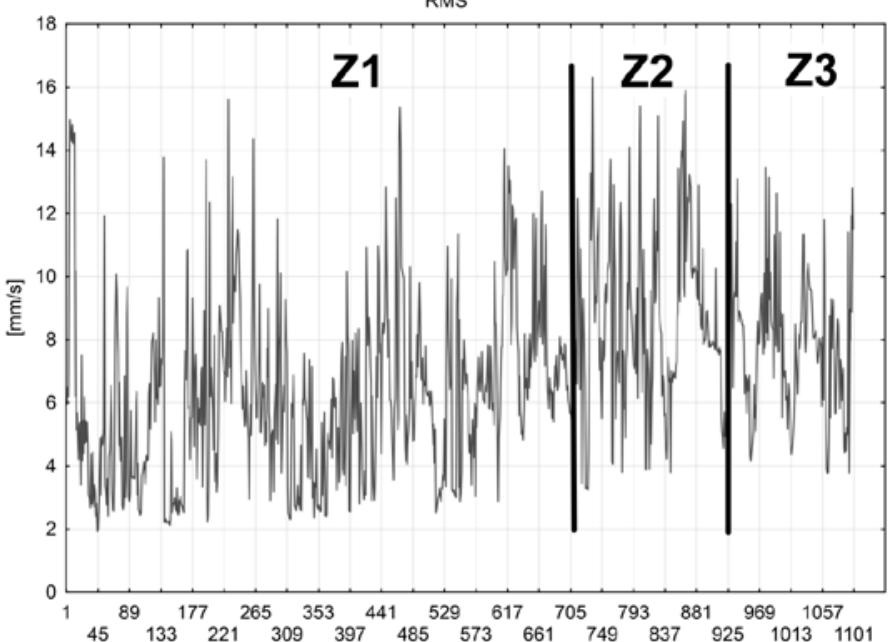

Fig. 9. Case study data: vibration trends for Acc and RMS features

Table 9. Case study data: confussion matrix for best performance MLP ANN with 9 input features

\begin{tabular}{|c|c|c|c|c||}
\hline & Z1 & Z2 & Z3 & All cases \\
\hline Total & 699 & 238 & 163 & 1100 \\
\hline Correct & 689 & 116 & 153 & 958 \\
\hline Incorrect & 10 & 122 & 10 & 142 \\
\hline Correct (\%) & 98.5694 & 48.7395 & 93.8650 & 87.091 \\
\hline Incorrect (\%) & 1.4306 & 51.2605 & 6.1350 & 12.909 \\
\hline
\end{tabular}

Table 11. Case study data: modeling power for each feature and its importance to $P C$ model

\begin{tabular}{|c|c|c|c||}
\hline & Feature & Power & Importance \\
\hline Acc & 2 & 0.961748 & 1 \\
\hline PeakPeak & 6 & 0.955579 & 2 \\
\hline Acc_500_1000 & 4 & 0.950476 & 3 \\
\hline Acc_1000_2000 & 5 & 0.939676 & 4 \\
\hline Acc_2_500 & 3 & 0.924648 & 5 \\
\hline Def & 8 & 0.779565 & 6 \\
\hline Kurtosis MVX & 9 & 0.672782 & 7 \\
\hline Kurtosis Postprocess & 7 & 0.642616 & 8 \\
\hline RMS & 1 & 0.288415 & 9 \\
\hline \hline
\end{tabular}

Table 10. Case study data: eignevalues, individual and cumulative variance for PCs

\begin{tabular}{||c|c|c|c|}
\hline & Eigenvalues & \% Total variance & Cumulative \% \\
\hline PC1 & 5.440144 & 60.44605 & 60.44605 \\
\hline PC2 & 1.675361 & 18.61512 & 79.06117 \\
\hline PC3 & 0.828145 & 9.20161 & 88.26278 \\
\hline
\end{tabular}

Table 12. Case study data: confussion matrix for best performance MLP ANN with 6 input features

\begin{tabular}{||c|c|c|c|c||}
\hline & Z1 & Z2 & Z3 & All cases \\
\hline Total & 495 & 168 & 107 & 770 \\
\hline Correct & 478 & 132 & 101 & 711 \\
\hline Incorrect & 17 & 36 & 6 & 59 \\
\hline Correct (\%) & 96.5657 & 78.5714 & 94.3925 & 92.3377 \\
\hline Incorrect (\%) & 3.4343 & 21.4286 & 5.6075 & 7.6623 \\
\hline
\end{tabular}

\section{Conclusion}

Implementation of ANN techniques in predictive maintenance of rotating machines based on vibration measurement and analysis can help in solving complex problems especially in presence of lack of highly skilled vibration analysts. However, for the reliable ANN an optimal set of vibration features must be defined. In this paper we demonstrated PCA as one of the possible technique for input features 
space dimension reduction and optimal selection of input features based on vibration measurement.

In case of bearing faults combined with four levels of imbalance introduced on test rig, vibration features based on overall acceleration and vibration velocity as well as spectral extractions at bearing fault frequencies were the best choice of input features. The ANN with better performance is generated and classification rate is raised by $14 \%$. In case of real life application on the port crane, the classification rate is raised by $5 \%$ through exclusion of overall vibration velocity and kurtosis parameters. In later case, RMS value of vibration velocity is irrelevant as an input feature, since all bearing fault cases correspond to the same level of imbalance. However in both cases kurtosis parameters are irrelevant. This is an interesting conclusion since it is believed that kurtosis parameter is the preferred vibration feature for bearing fault identification in the presence of variable load and speed of the machine.

Acknowledgement: The research work financed with the means of the State Ministry of science and technological development (Serbia) in the years 2011-2015 as a research project "The application of information technologies in the ports of Serbia from the monitoring of machines to the networked system with the EU environment"

\title{
References
}

1. Baillie D, Mathew J. Diagnosing Rolling Element Bearing Faults with Artificial Neural Networks. Acoustics Australia 1994; $22(3)$ : 79-84.

2. Bartkowiak A, Zimroz R. Sparse PCA for gearbox diagnostics. Computer Science and Information Systems (FedCSIS) 2011: 25-31.

3. Bishop C. Neural Networks for Pattern Recognition. Oxford University Press, 1995.

4. Czech P. Classification of fault diagnosis in a gear wheel by used probabilistic neural network, fast Fourier transform and principal component analysis. Transport Problems: an International Scientific Journal 2007: 99-106.

5. Georgijevic $\mathrm{M}$ et all. The application of information technologies in the ports of Serbia from the monitoring of machines to the networked system with the EU environment. Project TR35036 financed by the Serbian Ministry of Science and Technological Development of Republic of Serbia, 2011-2015.

6. Hoon S, Worden K, Farrar C. Novelty Detection under Changing Environmental Conditions. SPIE's 8th Annual International Symposium on Smart Structures and Materials, Newport Beach, CA 2001.

7. Jyh-Shing R J, Chuen-Tsai S, Mizutani E. Neuro-fuzzy and soft computing: a computational approach to learning and machine intelligence. MATLAB curriculum series. Prentice Hall, 1997.

8. Lazarz B, Wojnar G, Czech P. Early fault detection of toothed gear in exploitation conditions. Eksploatacja i Niezawodnosc - Maintenance and Reliability 2011; 1(49): 68-77.

9. Malhi A, Gao R X. PCA-based feature selection scheme for machine defect classification. Instrumentation and Measurement, IEEE Transactions 2004; 53 (6): 1517 - 1525.

10. Sick B. On-Line And Indirect Tool Wear Monitoring In Turning With Artificial Neural Networks: A Review Of More Than A Decade Of Research. Mechanical Systems and Signal Processing 2002; 16(4): 487-546, http://dx.doi.org/10.1006/mssp.2001.1460.

11. Tranter J. Mobius Institute Vibration training manual - category III. Mobius Institute, 2009.

12. Veelenturf L. Analysis and Applications of Artificial Neural Networks. Prentice Hall, 1995.

13. Worden K, Sohn H, Farrar C. R. Novelty Detection in a Changing Environment: Regression and Interpolation Approaches. Journal of Sound and Vibration 2002; 258 (4): 741-761, http://dx.doi.org/10.1006/jsvi.2002.5148.

14. Zhong B. Developments in intelligent condition monitoring and diagnostics. System Integrity and Maintenance, 2nd Asia-Pacific Conference (ACSIM2000) Brisbane Australia 2000; 1-6.

15. Zimroz R, Bartkowiak A. Investigation on Spectral Structure of Gearbox Vibration Signals by Principal Component Analysis for Condition Monitoring Purposes. Journal of Physics 2011; Conference Series 305: article number 012075.

16. Zuber N. Automation of rotating machinery failures by the means of vibration analysis. PhD Thesis, Faculty of Technical Sciences - University of Novi Sad, 2010.

17. Zuber N, Ličen H, Bajrić R. An innovative approach to the condition monitoring of excavators in open pits mines, Technics Technologies Education Management - TTEM 2010; 5(3): 841-847.

18. Zuber N, Cvetkovic D, Bajric R. Multiple fault identification using vibration signal analysis and artificial intelligence methods. Acoustics \& Vibration of Mechanical Structures 2013; 430: 63-69, http://dx.doi.org/10.4028/www.scientific.net/amm.430.63.

19. Zuber N, Cvetkovic D. Rolling element bearings fault identification in rotating machines, existing methods of vibration signal processing techniques and practical considerations. Acoustics \& Vibration of Mechanical Structures 2013; 430: 70-77, http://dx.doi.org/10.4028/www. scientific.net/amm.430.70.

20. Zuber N, Bajric R, Sostakov R. Gearbox faults identification using vibration signal analysis and artificial intelligence methods. Eksploatacja i Niezawodnosc - Maintenance and Reliability 2014; 16 (1): 61-65.

\author{
Ninoslav ZUBER \\ Faculty of Technical Sciences \\ University of Novi Sad \\ Trg Dositeja Obradovica 6, Serbia
}

Rusmir BAJRIĆ

EPC Elektroprivreda $\mathrm{BiH}$

Coal Mines Kreka

Mije Keroševica 1,

Tuzla, Bosnia and Herzegovina

E-mails: zuber@uns.ac.rs, rusmir.bajric@gmail.com 